\title{
The 8.2 ka cooling event related to extensive melting of the Greenland Ice Sheet
}

H. Ebbesen ${ }^{1}$, A. Kuijpers ${ }^{1}$, M. Moros ${ }^{2}$, J. Lloyd ${ }^{3}$, M.-S. Seidenkrantz ${ }^{4}$, and S. Troelstra ${ }^{5}$

${ }^{1}$ Geological Survey of Denmark and Greenland, Denmark

${ }^{2}$ Institute for Baltic Sea Research, Warnemünde, Germany

${ }^{3}$ Department of Geography, University of Durham, UK

${ }^{4}$ Institute of Geology, Aarhus University, Denmark

${ }^{5}$ Department of Paleoclimatology and Geomorphology, Vrije Universiteit, The Netherlands

Received: 3 September 2008 - Accepted: 11 September 2008 - Published: 27 October 2008 Correspondence to: H. Ebbesen (heb@geus.dk)

Published by Copernicus Publications on behalf of the European Geosciences Union.

8.2 ka event related to melting of the

Greenland Ice Sheet

H. Ebbesen et al.

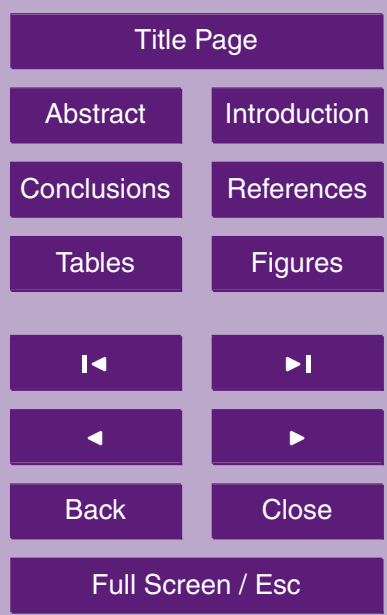

Printer-friendly Version

Interactive Discussion

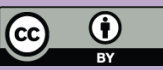




\section{Abstract}

The North Atlantic cooling event at 8200 calibrated (cal) yr BP has been attributed to effects of an extensive freshwater discharge from the Hudson Strait (Barber et al., 1999; Leverington et al., 2002). Here we present sedimentary records from 5 cores collected 5 from the Greenland shelf. These document high magnetic susceptibility (MS) values related to massive silt deposition, which is ascribed to large-scale melt water outflow from the Greenland Ice Sheet (GIS) spanning the centuries before 8200 cal yr BP and ending after $8000 \mathrm{cal}$ yr BP. XRF trace element composition and foraminiferal fauna's provide additional evidence for excessive melt-water production, which can be related to early Holocene warming of the circum-Arctic region including Greenland. Planktonic foraminiferal fauna data from the southern Davis Strait indicate the widespread presence of negative salinity anomalies reaching far offshore Greenland. Significant freshening of surface waters around Greenland prior to $8200 \mathrm{cal}$ yr BP must have led to a slowdown of the deep-water formation which thus implies that significant melting 15 of the GIS should be taken into account when discussing driving mechanisms behind the 8200 cal yr BP cooling event.

\section{Introduction}

Today we witness that melting of the GIS is a very important issue when discussing possible future climatic changes. Rising global average temperature may result in increased ice sheet melting and this process may even accelerate in the future. From 1979 to 2002 the area of the inland ice influenced by melting became enlarged by $16 \%$ (Steffen et al., 2004). Satellite observations tell us that during the last decade ice discharge from GIS has led to a doubling of the annual ice sheet mass deficit (Rignot et al., 2006). During the past decades the temperature of the Arctic region has increased twice as much as in the rest of the world (ACIA, 2004), demonstrating that the Arctic region has the highest sensitivity to future changes (Overpeck et al., 1997). Thus, today
4, 1219-1235, 2008

$8.2 \mathrm{ka}$ event related to melting of the

Greenland Ice Sheet

H. Ebbesen et al.

\section{Title Page}

Abstract

Introduction

Conclusions

References

Tables

Figures

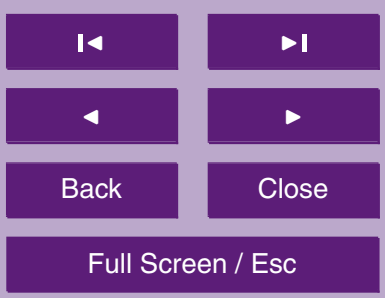

Printer-friendly Version

Interactive Discussion

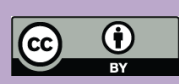


we recognize melting of GIS as an important factor in future climate scenarios, not only because of sea-level rise, but also due to its possible impact on North Atlantic thermohaline circulation, which may eventually result in marked cooling of the North Atlantic. Past climate reconstructions, in fact, attribute marked regional cooling to the effect of 5 melt-water discharge into the North Atlantic, which may provide a possible analogue also for future climate scenarios. For the early Holocene, evidence of such a North Atlantic cooling episode was first discovered in Greenland ice cores (Johnsen et al., 1992). This 8200 cal yr BP cooling event has afterwards been recognized in records from several sites in the North Atlantic region (Klitgaard-Kristensen et al., 1998; Rise10 brobakken et al., 2003; Rohling and Pälike, 2005). A generally accepted explanation for the origin of this event is a massive fresh-water discharge from the Hudson Strait, Canada, where large glacial lakes drained during the period around $8200 \mathrm{cal}$ yr BP (Barber et al., 1999; Leverington et al., 2002). Only limited attention has, however, been given to the possible role of melting of the GIS, which represents the largest ice

mass of the Northern Hemisphere since the early Holocene. Here we present early Holocene high-resolution records from sediment cores collected in Greenland coastal waters. Our data indicate strongly enhanced melt-water production from Greenland in the period immediately preceding 8200 cal yr BP.

\section{Results and discussion}

20 We have analyzed the sedimentary records of the time interval around $8200 \mathrm{cal}$ yr BP in the Greenland cores in order to find possible evidence of a GIS melt-water discharge maximum in relation to the 8200 cal yr BP event. The magnetic records from the studied sediment cores (Fig. 1a) reflect lithological variations, with high values of MS being here indicative of significant discharge of (suspended) matter associated with extensive melt-water plumes from the GIS. In fact, all cores show massive silt deposition with maximum values of MS in the period immediately prior to $8200 \mathrm{cal} \mathrm{yr} \mathrm{BP} \mathrm{(Fig.} \mathrm{2c,}$ d, e). Interestingly, the maximum values of MS reflecting melt-water discharge ap-
4, 1219-1235, 2008

8.2 ka event related to melting of the

Greenland Ice Sheet

H. Ebbesen et al.
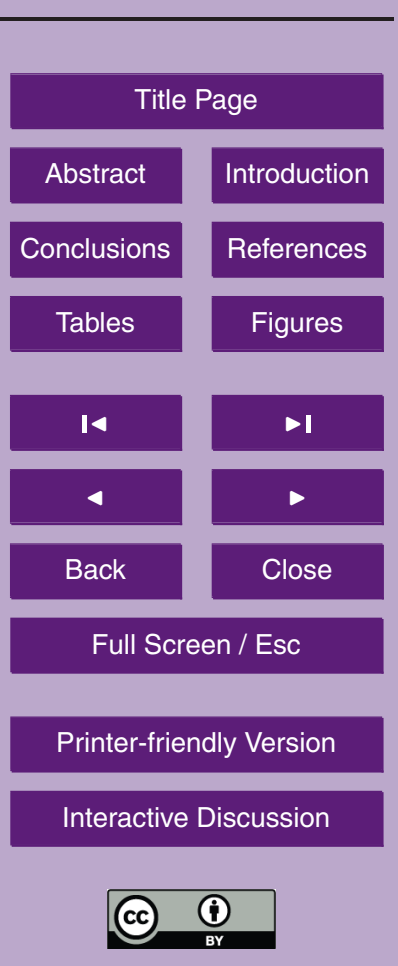
pear at different times when comparing the core records from Disko Bugt and Ameralik Fjord. At the southern location, Ameralik (Fig. 1a), the maximum melt-water discharge occurred early ( 8700 cal yr BP), while it appears around 8250 cal yr BP in the two cores from Disko Bugt. After these maxima in melt-water discharge in all three cases the MS 5 values gradually decreased during the centuries following $8200 \mathrm{cal}$ yr BP (Fig. 2c, d, e). This suggests a decreasing melt-water production associated with slower retreat of Greenland glaciers, terminating at first in the southernmost core (8000 cal yr BP, Fig. 2e). In the cores from Disko Bugt this occurred around 7750 calyr BP (Fig. 2d) and $7200 \mathrm{cal}$ yr BP, respectively (Fig. 2c). When comparing the setting of these latter 10 two cores, it can be noted that the youngest age is found for the core located off the presently active, marine-based Jakobshavn Isbrae, whereas the other core record illustrates melt-water outflow conditions in a fjord more to the southeast and probably reflects an earlier change from a marine-based to an onshore ice margin position.

Elevated XRF values of land-derived trace elements iron and titanium (Fig. $3 \mathrm{~h}$ and 15 i) in the Ameralik Fjord core DA04-41P during this particular period confirm the melt water outflow from the GIS. The analysis of benthic foraminifera from the same area (Ameralik) (Fig. 3a-f) also supports the theory of extensive melt-water outflow prior to 8200 cal yr BP. Dominance of the species Elphidium (E) excavatum and Cassidulina (C) reniforme confirm a very cold and unstable environment at the seafloor (Steinsund et al., 2000) from 8350-7800 cal yr BP (Fig. 3g, f). E. excavatum has been found to dominate areas influenced by high glacial melting (Korsun and Hald, 2000). Enormous amounts of melt water before $8200 \mathrm{cal}$ yr BP presumably led to the formation of a thick, low-salinity upper water mass preventing vertical mixing of the water column leading to poor bottom water ventilation. It implies that the warmer, more saline Irminger Sea

Water (ISW) entrained at subsurface depth by the West Greenland Current (WGC) did not cross the sill $(120 \mathrm{~m})$ at the entrance of the Ameralik Fjord. The low frequency of the species Astrononion ( $A$ ) gallowayi (Fig. 3e) confirm a low bottom current activity (Rytter et al., 2002) prior to 8200 cal yr BP supporting a period characterised by a significant melt water (surface) outflow.
4, 1219-1235, 2008

8.2 ka event related to melting of the

\section{Greenland Ice Sheet}

H. Ebbesen et al.
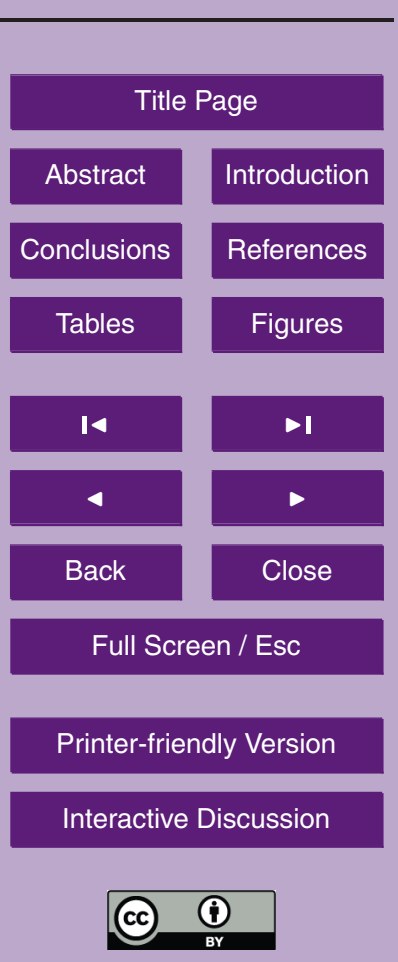
After 7800 cal yr BP the fauna changed dramatically (Fig. 3) indicating significant hydrographic changes. The distinct decrease of $E$. excavatum and $C$. reniforme (Fig. $3 \mathrm{~g}$, f), and simultaneous increase in Globobulimina (G) auriculata (Fig. 3c) and in general foraminiferal production (flux, Fig. $3 b$ ) indicate a higher food availability probably 5 through increased primary production and a significant improvement of foraminiferal living conditions. At the same time the abundance of $A$. gallowayi (Fig. 3e) increase indicating bottom current activity. The species Nonionellina $(N)$ labradorica (Fig. $3 d$ ) is also frequent, which suggests the nearby presence of water mass boundaries. Concurrently, the diatom flora indicates warming of the surface waters (Ren et al., 2008). 10 This change in the benthic foraminiferal and diatom assemblages coincide with the significant drop in MS and the simultaneously decrease in land-derived trace elements (Fig. 3h and i) seen at 7800 cal yr BP. These data thus confirm a stronger inflow of ISW into the fjord combined with a marked decrease in melt-water discharge. This may, amongst others, be linked here to a retreat of originally marine-based glaciers. The 15 significant change in the foraminiferal fauna and MS records with various proxies not returning to values found prior to $7800 \mathrm{cal} \mathrm{yr} \mathrm{BP} \mathrm{(Fig.} \mathrm{3)} \mathrm{implies} \mathrm{that} \mathrm{the} \mathrm{hydrographic}$ conditions associated with massive melt-water discharge from nearby glaciers did not re-appear.

Lower resolution MS records have previously been published from South Greenland 20 (Igaliku Fjord, PO 243-451) (Kuijpers et al., 1999; Lassen et al., 2004) and from the shelf off Southeast Greenland (DS97-4P) (Kuijpers et al., 2003) (Fig. 1a). The MS data of these two cores (Fig. 2a, b) show the same pattern as found west off Greenland. Both records clearly show maximum values prior to $8200 \mathrm{cal} y \mathrm{r} \mathrm{BP}$, pointing to a significant deposition of suspended matter related to a strong melt-water discharge.

25 Similarly as off West Greenland (Fig. 2c-e), the records from these southern sites display a gradual upward decrease in MS values indicating a decreasing melt-water discharge. A large-scale meltwater impact on ocean currents off the shelf of South Greenland between ca. 8400 and $7800 \mathrm{calyr}$ BP is also demonstrated by the trace element composition of a sediment core retrieved from Eirik Drift (Carlson et al., un-
4, 1219-1235, 2008

8.2 ka event related to melting of the Greenland Ice Sheet

H. Ebbesen et al.

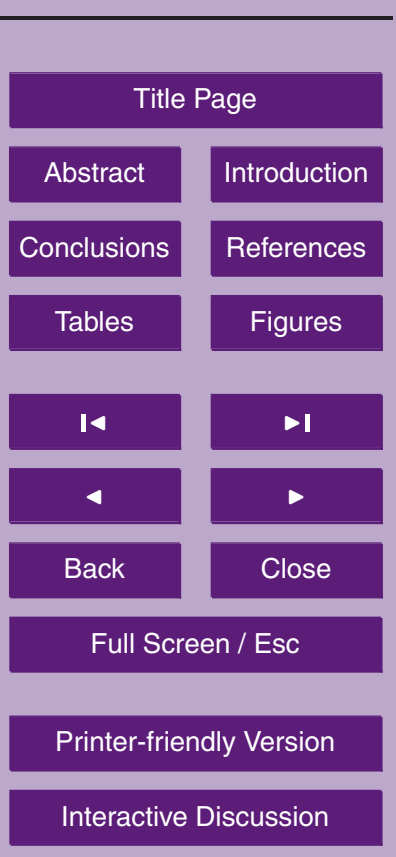


published data). A marked glacier retreat and an associated enhanced melt-water production prior to $8400 \mathrm{calyr}$ BP has been identified from adjacent regions in the Arctic, in particular from the Nares Strait region (Mudie et al., 2004). In the Spitsbergen region sea-surface temperatures (Ebbesen et al., 2007; Sarnthein et al., 2003) 5 show a significant cooling already at $8800 \mathrm{cal}$ yr BP. This cooling does not occur as a short event like the 8200 cal yr BP but spans a longer period, presumably related to a southward expansion of Arctic Water masses (Ebbesen et al., 2007). A planktic foraminiferal record from southern Davis Strait (core DA04-31P) supports the scenario of a large-scale melt water episode affecting waters around Greenland around 8200 to 108000 cal yr BP (Fig. 4). The relatively high amount of T. quinqueloba and high productivity of planktic foraminifera around 8200-8000 cal yr BP (Fig. 4c and d) bear witness of a frontal zone nearby, possibly the front between WGC-entrained Polar Water/melt water masses and more saline, Atlantic-derived (ISW) water masses from the central Labrador Sea (Fig. 1b). After 8000 cal yr BP the foraminiferal assemblage changed and 15 productivity decreased suggesting a frontal retreat towards Greenland, where today it is found over the shelf (Fig. 4d). Around 7800 cal yr BP the melt water front had moved inshore into the fjords (Fig. 1b).

It is noteworthy that neither of these records shows an actual cooling event at 8200 cal yr BP, even though several of them yield a sufficiently high resolution to detect 20 this event. Sediment cores from along the eastern margin of North America, including the Hudson Strait showed no evidence for a change in the surface and deep ocean environment around the cold event (Keigwin et al., 2005), even though the sites should have been directly affected by a fresh-water discharge from the glacial lakes in North America. In fact, the 8200 cooling event has only been found as a spike in areas of the 25 North Atlantic directly influenced by the North Atlantic Current, but not in those areas mainly influenced by the East and West Greenland Current or by the Baffin-Labrador Current system. These currents are all characterised by the presence of a low-salinity, cold surface water layer and are often ice-loaded, which may exclude recording of a cooling event as observed elsewhere in the North Atlantic.

$8.2 \mathrm{ka}$ event related to melting of the Greenland Ice Sheet

H. Ebbesen et al.
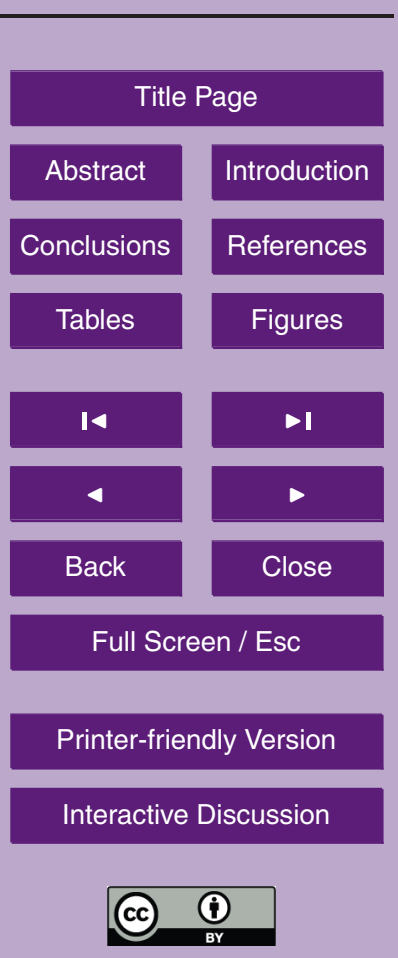
Studies along the eastern margin of North America (Keigwin et al., 2005) support conclusions from an earlier research (Kaufmann et al., 2004) stating that the timing of the Holocene Thermal Optimum around Hudson Bay was significantly delayed (until ca 7000 cal yr BP) when compared with Alaska and northwest Canada (beginning ca $511000 \mathrm{cal}$ yr BP). Our results provide additional evidence for the widespread presence of a thick and cold, low-salinity melt-water layer offshore Greenland and north-eastern Canada from well before $8200 \mathrm{calyr}$ BP to shortly after that time. This scenario is supported by studies dealing with Labrador Sea Water formation (Hillaire-Marcel et al., 2001) showing that in the early Holocene Labrador Sea deep convection did not occur 10 before ca. 7500 cal yr BP.

Thus, the marine records from Greenland and Spitsbergen indicate that melt water and low-salinity water masses expanded in both regions prior to $8200 \mathrm{cal}$ yr BP. This can be related to early Holocene warming of the circum-Arctic region including Greenland, which led to enhanced GIS and glacier melting around the Arctic. Subsequent marked freshening of the East and West Greenland Current system as well as the Baffin-Labrador Current region led to slowdown of high-latitude deep convection and thus contributed to North Atlantic cooling. We emphasize that we do not exclude the drainage of the glacial lakes in North America as a possible mechanism for eventually causing the spike of the 8200 cooling event. We propose, however, large-scale melting of the GIS prior to 8200 cal yr BP as an additional, important factor to be taken into account when discussing and modelling driving mechanisms behind this early Holocene North Atlantic cooling event.

Acknowledgements. Funding was provided by the Carlsberg Foundation, The Geological Survey of Denmark and Greenland (GEUS) and the Danish Natural Science Research Council (Grant 21-04-0336 to AKU and MSS).
4, 1219-1235, 2008

8.2 ka event related to melting of the

Greenland Ice Sheet

H. Ebbesen et al.

Title Page

Abstract

Introduction

Conclusions

References

Tables

Figures

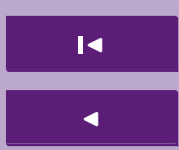

$>\mathbf{I}$

Back

$\checkmark$

Close

Full Screen / Esc

Printer-friendly Version

Interactive Discussion

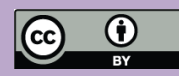




\section{References}

Barber, D. C., Dyke, A., Hillaire-Marcel, C., Jennings, A. E., Andrews, J. T., Kerwin, M. W., Bilodeau, G., McNeely, R., Southon, J., Morehead, M. D., and Gagnon, J. M.: Forcing of the cold event 8200 years ago by catastrophic drainage of laurentide lakes, Nature, 400, 344-348, 1999.

Leverington, D. W., Mann, J. D., Teller, J. T.: Changes in the bathymetry and volume of glacial Lake Agassiz between 9200 and $7700{ }^{14} \mathrm{C}$ yr BP, Quat. Res., 57, 244-252, 2002.

Steffen, K., Nghiem, S. V., Huff, R., and Neumann, G.: The melt anomaly of 2002 on the Greenland Ice Sheet from active and passive microwave satellite observations, Geophys.

10 Res. Lett., 31(20), L20402, doi:10.1029/2004GL020444, 2004.

Rignot, E. and Kanagaratnam, P.: Changes in the Velocity Structure of the Greenland Ice Sheet, Science, 311(5763), 986-990, 2006.

Arctic Climate Impact Assessment (ACIA): Issued by the Fourth Arctic Council Ministrerial Meeting, Reykjavik, 2004.

Overpeck, J., Hughen, K., Hardy, D., Bradley, R., Case, R., Douglas, M., Finney, B., Gajevski, K., Jacoby, G., Jennings, A., Lamoureux, S., Lasca, A., MacDonald, G., Moore, J., Retelle, M., Smith, S., Wolfe, A., and Zielinski, G.: Arctic environmental change of the last four centuries, Science, 278, 1251-1256, 1997.

Johnsen, S. J., Clausen, H. B., Dansgaard, W., Fuhrer, K., Gundestrup, N., Hammer, C. recorded in a new Greenland ice core, Nature, 359, 311-313, 1992.

Klitgaard-Kristensen, D., Sejrup, H. P., Haflidason, H., Johnsen, S., and Spurk, M.: A regional 8200 cal. yr BP cooling event in northwest Europe, induced by final stages of the Laurentide ice-sheet deglaciation?, J. Quat. Sci., 13, 165-169, 1998.

Risebrobakken, B., Jansen, E., Andersson, C., Mjelde, E., and Hevrøy, K.: A high-resolution study of Holocene paleoclimatic and paleoceanographic changes in the Nordic Seas, Paleoceanography, 18(1), 1-14, 2003.

Rohling, E. J. and Pälike, H.: Centennial-scale climate cooling with a sudden cold event around 8,200 years ago, Nature, 434, 975-979, 2005.

30 Cuny, J., Rhines, P. B., and Kwok, R.: Davis Strait volume, freshwater and heat fluxes, DeepSea Res. I, 52, 519-542, 2005.

Tang, C. C. L., Ross, C. K., Yao, T., Petrie, B., DeTracey, B. M., and Dunlap, E.: The circulation,
4, 1219-1235, 2008

8.2 ka event related to melting of the

\section{Greenland Ice Sheet}

H. Ebbesen et al.

\section{Title Page}

Abstract

Introduction

Conclusions

References

Tables

Figures

14

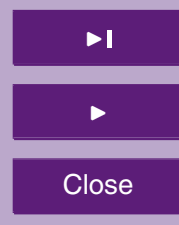

Back

Close

Full Screen / Esc

Printer-friendly Version

Interactive Discussion

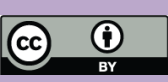


water masses and sea- ice of Baffin Bay, Prog. Oceanogr., 63, 183-228, 2004.

Seidenkrantz, M.-S., Aagaard-Sørensen, S., Sulsbrück, H., Kuijpers, A., Jensen, K. G., and Kunzendorf, H.: Hydrography and climate of the last 4400 years in a SW Greenland fjord: implications for Labradors Sea Palaeoceanography, The Holocene, 17(3), 387-401, 2007.

5 Stuiver, M., Reimer, P. J., and Reimer, R.: Calib radiocarbon calibration, Execute version 5.0.2 html, available online: calib.qub.ac.uk/calib/, 2006.

Reimer, P.: Marine Reservoir Correction Database, Queens University Belfast, available online: intcal.qub.ac.uk/marine/, 2005.

Steinsund, P. I., Polyak, L., Hald, M., Mikhailov, V., and Korsun, S.: Distribution of calcareous benthic foraminifera in recent sediments of the Barents and Kara Seas, J. Foraminiferal Res., 61-102, 1994.

Korsun, S. and Hald, M.: Seasonal dynamics of benthic foraminifera in a glacially fed fjord of Svaldbard, European arctic, J. Foraminiferal Res., 30(4), 251-271, 2000.

Rytter, F., Knudsen, K. L., Seidenkrantz, M.-S., and Eiríksson, J.: Modern distribution of ben15 thic foraminifera on the North Icelandic shelf and slope, J. Foraminiferal Res., 32, 217-244, 2002.

Ren, J., Jiang, H., Seidenkrantz, M.-S., and Kuijpers, A.: A diatom-based reconstructon of Early Holocene hydrographic and climatic change in a southwest Greenland fjord, Mar. Micropaleonthol., revised, 2008.

20 Kuijpers, A., Abrahamsen, N., Hoffmann, G., Hühnerbach, V., Konradi, P., Kunzendorf, H., Mikkelsen, N., Thiede, J., and Weinrebe, W.: Climate change and the Viking-age fjord environment of the Eastern Settlement, South Greenland, Geology of Greenland Survey Bulletin, 183, 61-67, 1999.

Lassen, S. J., Kuijpers, A., Kunzendorf, H., Hoffmann-Wieck, G., Mikkelsen, N., and Konradi, P.: Late-Holocene Atlantic bottom-water variability in Igaliku Fjord, South Greenland, reconstructed from foraminifera faunas, The Holocene, 14(2), 165-171, 2004.

Kuijpers, A., Troelstra, S. R., Prins, M. A., Linthout, K., Akhmetzhanov, A., Bouryak, S., Bachmann, M. F., Lassen, S., Rasmussen, T., and Jensen, J. B.: Late Quaternary sedimentary processes and ocean circulation changes at the Southeast Greenland margin, Mar. Geol., 195, 109-129, 2003.

Mudie, P. T., Rochon, A., Prins, M. A., Soenarjo, D., Troelstra, S. R., Levac, E., Scott, D. B., Roncaglia, L., and Kuijpers, A.: Late Pleistocene-Holocene Marine Geology of Nares Strait Region, Palaeoceanography from Foraminifera and Dinoflagellate Cysts, Sedimentology and

\section{2 ka event related to melting of the \\ Greenland Ice Sheet}

H. Ebbesen et al.
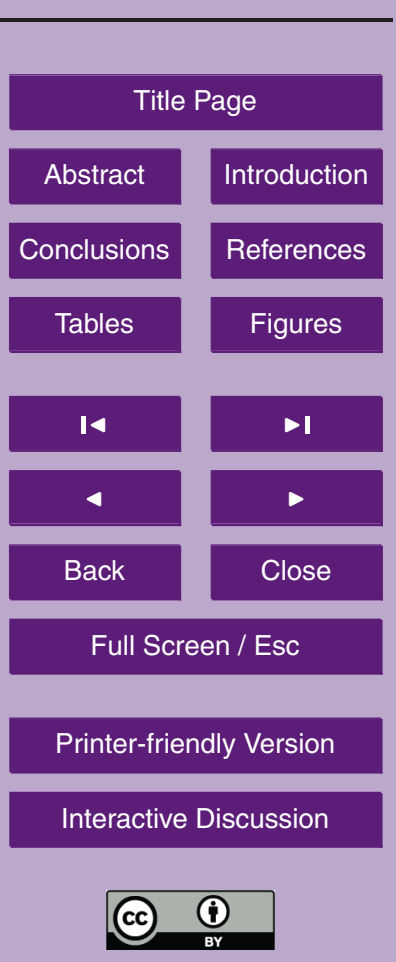
Stable Istopes, Polarforschung, 74(1-3), 169-183, 2004, appeared 2006.

Ebbesen, H., Hald, M., and Eplet, T.-H.: Lateglacial and Early Holocene climatic oscillation on the western Svalbard margin, European Arctic, Quat. Sci. Rev., 26, 1999-2011, 2007.

Sarnthein, M., Van Kreveld, S., Erlenkeuser, H., Grootes, P. M., Kucera, M., Pflaumann, U., and 5

Schulz, M.: Centennial-to-millennial-scale periodicities of Holocene climate and sediment injections off the western Barents shelf, $75^{\circ} \mathrm{N}$, Boreas, 32, 448-461, 2003.

Keigwin, L. D., Sachs, J. P., Rosenthal, Y., and Boyle, E. A.: The 8200 year BP event in the slope water system, western subpolar North Atlantic, Paleoceanography, 20, PA2003, doi:10.1029/2004PA001074, 2005.

10 Kaufmann, D. S., Ager, T. A., Anderson, N. J., Anderson, P. M., Andrews, J. T., Bartlein, P. J., Brubaker, L. B., Coats, L. L., Cwynar, L. C., Duvall, M. L., Dyke, A. S., Edwards, M. E., Eisner, W. R., Gajewski, K., Geirsdóttir, A., Hu, F., S., Jennings, A. E., Kaplan, M. R., Kerwin, M. W., Lozhkin, A. V., MacDonald, G. M., Miller, G. H., Mock, C. J., Oswald, W. W., Otto-Bliesner, B. L., Porinchu, D. F., Rühland, K., Smol, J. P., Steig, E. J., and Wolfe, B. B.: Holocene thermal maximum in the western Arctic (0-180 W), Quate. Sci. Rev., 23, 529-560, 2004.

Hillaire-Marcel, C., de Vernal, A., Bilodeau, G., and Weaver, A. J.: Absence of deep-water formation in the Labrador Sea during the last interglacial period, Nature, 410, 1073-1077, 2001.
4, 1219-1235, 2008

\section{2 ka event related to melting of the \\ Greenland Ice Sheet}

H. Ebbesen et al.

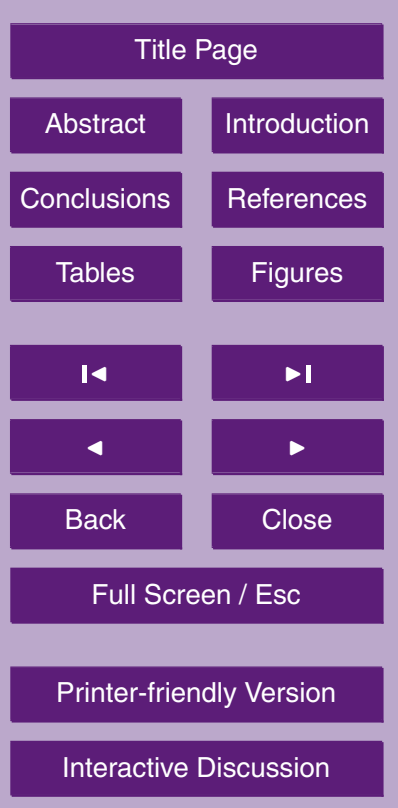


Table 1. A review of the AMS ${ }^{14} \mathrm{C}$ dates from the marine cores, used and correlated to, in the present study. The individual age models for each core were performed by using linearly interpolation in all cases. The AMS ${ }^{14} \mathrm{C}$ dates are to shown in Table 1. The radiocarbon ages were converted into calibrated years by using Calib version 5.0.2 $\left({ }^{14}\right)$ and a reservoir age correction of 400 years in accordance with ${ }^{15}$.

\begin{tabular}{|c|c|c|c|c|c|c|c|c|}
\hline $\begin{array}{c}\text { Core ID } \\
\text { (water depth) }\end{array}$ & $\begin{array}{l}\text { core depth } \\
(\mathrm{cm})\end{array}$ & lab. Ref & material dated & $\begin{array}{c}{ }^{14} \mathrm{C} \text { age corrected } \\
400 \mathrm{yr}\end{array}$ & 1-sigma & $\begin{array}{c}95.4 \%(2 \sigma) \\
\text { cal age ranges }\end{array}$ & $\begin{array}{l}\text { Age used } \\
\text { (cal yr BP) }\end{array}$ & References \\
\hline \multirow{4}{*}{$\begin{array}{l}\text { DA04-41P } \\
(744 \mathrm{~m})\end{array}$} & $675.5-676.5$ & AAR-10110 & Shell (colus holboelli) & 6739 & 43 & $7518-7694$ & 7606 & \multirow[t]{4}{*}{ Present study } \\
\hline & $680-681$ & AAR-10111 & Shell (bathyarca glacialis) & 6808 & 43 & $7579-7773$ & 7676 & \\
\hline & $765-767$ & AAR-10792 & Benthic forams & 7125 & 65 & 7854-8142 & 7998 & \\
\hline & $790-793$ & AAR-10662 & Benthic forams & 7365 & 75 & $8051-8375$ & 8213 & \\
\hline \multirow{3}{*}{$\begin{array}{c}\text { DA00-04 } \\
(256 \mathrm{~m})\end{array}$} & 395 & Poz-8141 & Benthic forams & 6120 & 40 & $6920-7150$ & 7035 & \multirow[t]{3}{*}{ Moros } \\
\hline & 456 & Poz-8143 & Shell+Benthic forams & 6320 & 40 & $7155-7344$ & 7250 & \\
\hline & 730 & KIA23366 & Benthic forams & 6910 & 40 & $7667-7873$ & 7770 & \\
\hline DS97-4P & 42.5 & UtC 10134 & Planktic forams & 5380 & 60 & $6014-6311$ & 6163 & \multirow[t]{3}{*}{ Kuijpers et al. (2003) } \\
\hline \multirow{2}{*}{$(620 \mathrm{~m})$} & 92.5 & UtC 10133 & Planktic forams & 6550 & 80 & $7300-7589$ & 7445 & \\
\hline & 132 & UtC 10137 & Planktic forams & 8860 & 80 & $9797-10250$ & 10024 & \\
\hline \multirow{3}{*}{$\begin{array}{l}\text { DA00-06 } \\
(363 \mathrm{~m})\end{array}$} & 430 & KIA23024 & Forams & 7270 & 47 & $7640-7816$ & 7713 & \multirow[t]{3}{*}{ Lloyd et al. (2005) } \\
\hline & 650 & KIA23025 & Forams & 7430 & 70 & $7734-8018$ & 7889 & \\
\hline & 891 & AAR6839 & Bivalve & 7843 & 72 & $8150-8420$ & 8320 & \\
\hline PO243-451 & 99 & AAR-5046 & Plant & 2235 & 45 & $2171-2453$ & 2312 & Kuijpers et al. (1999) \\
\hline$(304 \mathrm{~m})$ & 126 & AAR-5047 & Shell & 7775 & 65 & 8506-8927 & 8717 & Lassen et al. (2004) \\
\hline DA04-31P & $0-6$ & AAR-10681 & Forams & 965 & 40 & $792-1006$ & 899 & Present study \\
\hline$(2525 \mathrm{~m})$ & 38 & AAR-9982 & Forams & 8020 & 65 & 8840-9245 & 9042 & \\
\hline
\end{tabular}

\section{$8.2 \mathrm{ka}$ event related to melting of the \\ Greenland Ice Sheet}

H. Ebbesen et al.

\section{Title Page}

\section{Abstract}

Introduction

Conclusions

References

Tables

Figures
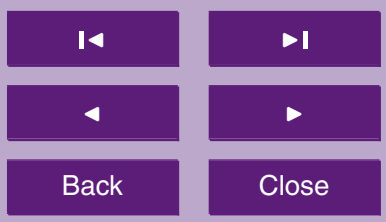

Full Screen / Esc

Printer-friendly Version

Interactive Discussion 


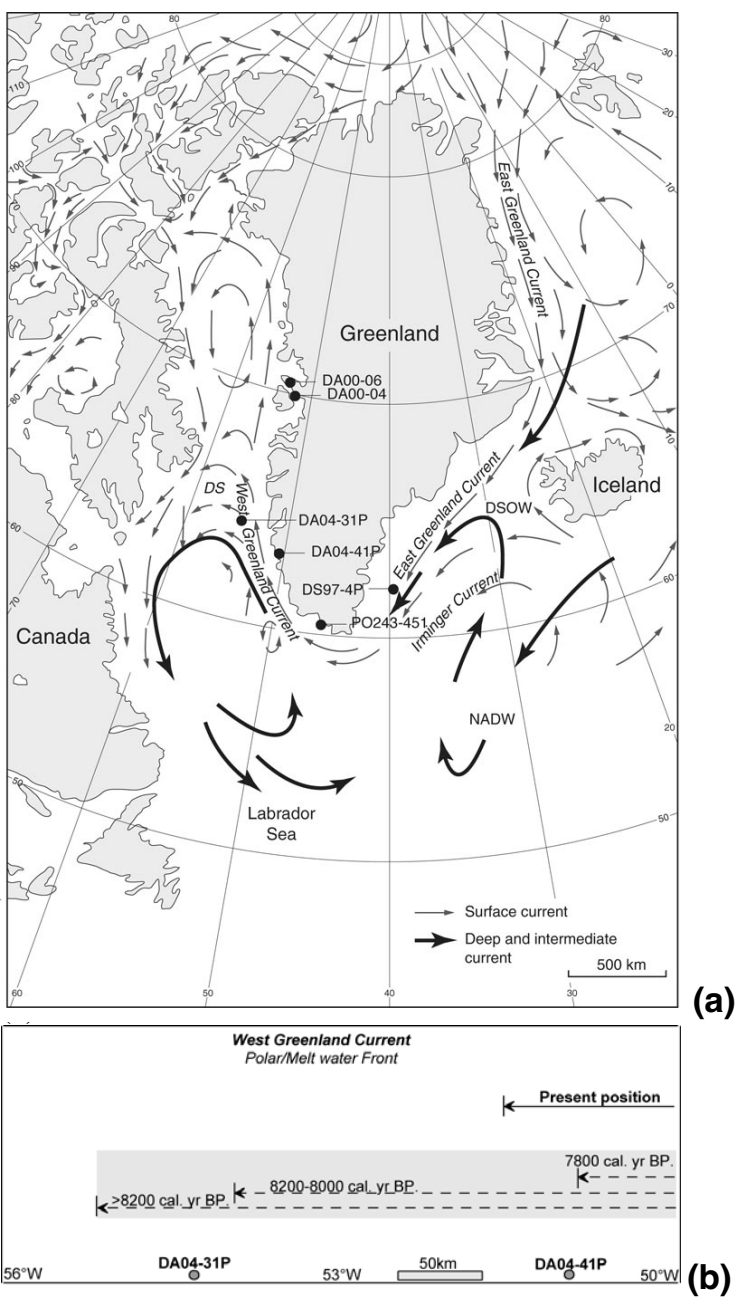

Fig. 1.
4, 1219-1235, 2008

$8.2 \mathrm{ka}$ event related to melting of the Greenland Ice Sheet

H. Ebbesen et al.

Title Page

\begin{tabular}{c|c|}
\hline Abstract & Introduction \\
\hline Conclusions & References \\
\hline Tables & Figures \\
\hline I4 & - I \\
\hline 4 & - \\
\hline Back & Close \\
\hline Full Screen / Esc
\end{tabular}

Printer-friendly Version

Interactive Discussion

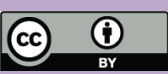




\section{2 ka event related to melting of the \\ Greenland Ice Sheet}

Fig. 1. (a) Location map of the North Atlantic region. The modern surface ocean circulation is shown here. DS; Davis Strait and NADW; North Atlantic Deep Water. The investigated marine sediment cores were collected at three sites off West Greenland. These data were compared with sedimentary records from marine cores collected in South Greenland (Igaliku Fjord core PO 243-451) and from the Southeast Greenland shelf (core DS97-04P). One of the West Greenland core sites is located in the Ameralik Fjord (Lysefjord, piston core DA04-41P) near Nuuk, and the two other sites are located further to the north in the Disko Bugt area (DA0004 and DA00-06). In addition we support these data with a planktic record from DS (DA04-31P). Today the West Greenland core sites are mainly influenced by waters from the West Greenland Current (WGC). At the surface, the WGC transports cold, low-salinity water masses including glacier melt-water and Polar Water derived from the East Greenland Current (EGC). At greater (>150-200 m) water depths the WGC entrains warmer, saline Atlantic water-masses derived from the Irminger Current (IC) (Cuny et al., 2005; Tang et al., 2004). In Ameralik Fjord the depth of the upper boundary of the Atlantic water masses corresponds to the depth of a sill found at the fjord entrance. This makes this site especially sensitive to Atlantic Water variability, as warm, saline water from the IC is only found at this site during periods of expanded IC water inflow into the Labrador Sea and reduced melt-water outflow (Seidenkrantz et al., 2007). (b) Illustration of movements of West Greenland Current, Polar/Melt water Front from before 8200 cal yr BP until 7800 cal yr BP in a transect between DA04-31P in west and DA04-41P in east, in the Ameralik fjord.

H. Ebbesen et al.

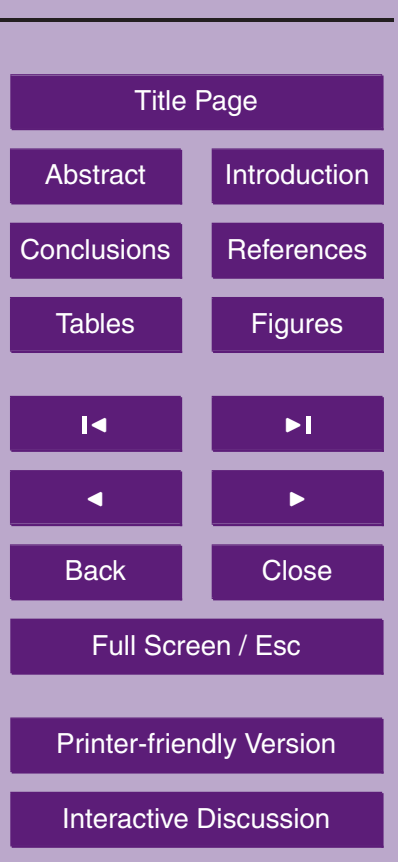

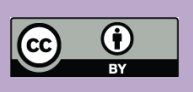




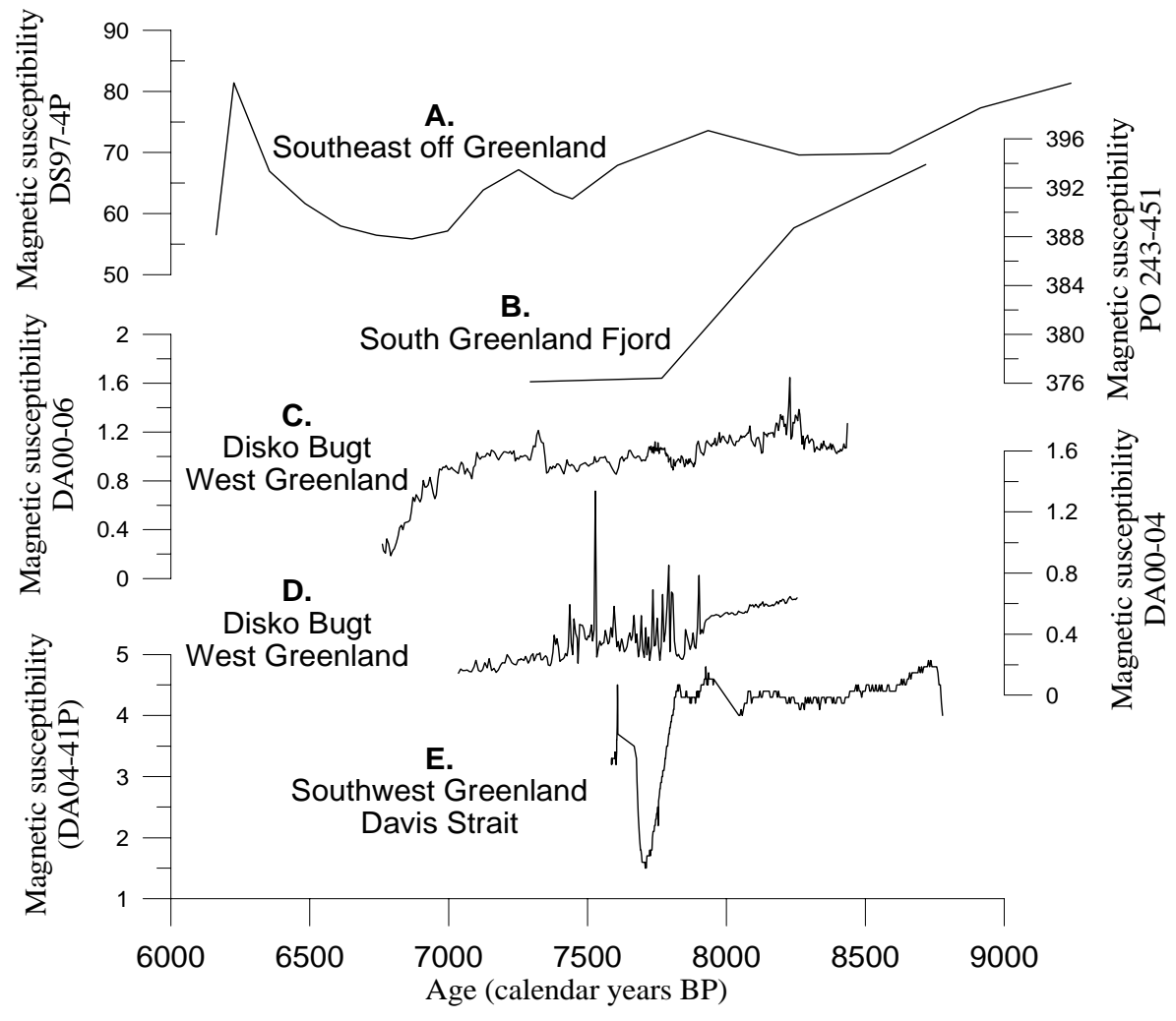

4, 1219-1235, 2008

8.2 ka event related to melting of the

Greenland Ice Sheet

H. Ebbesen et al.

Title Page

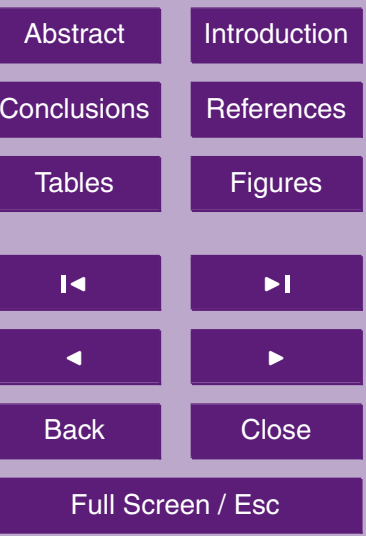

Printer-friendly Version

Fig. 2. Magnetic susceptibility (MS) from five marine sediment cores.

Interactive Discussion 


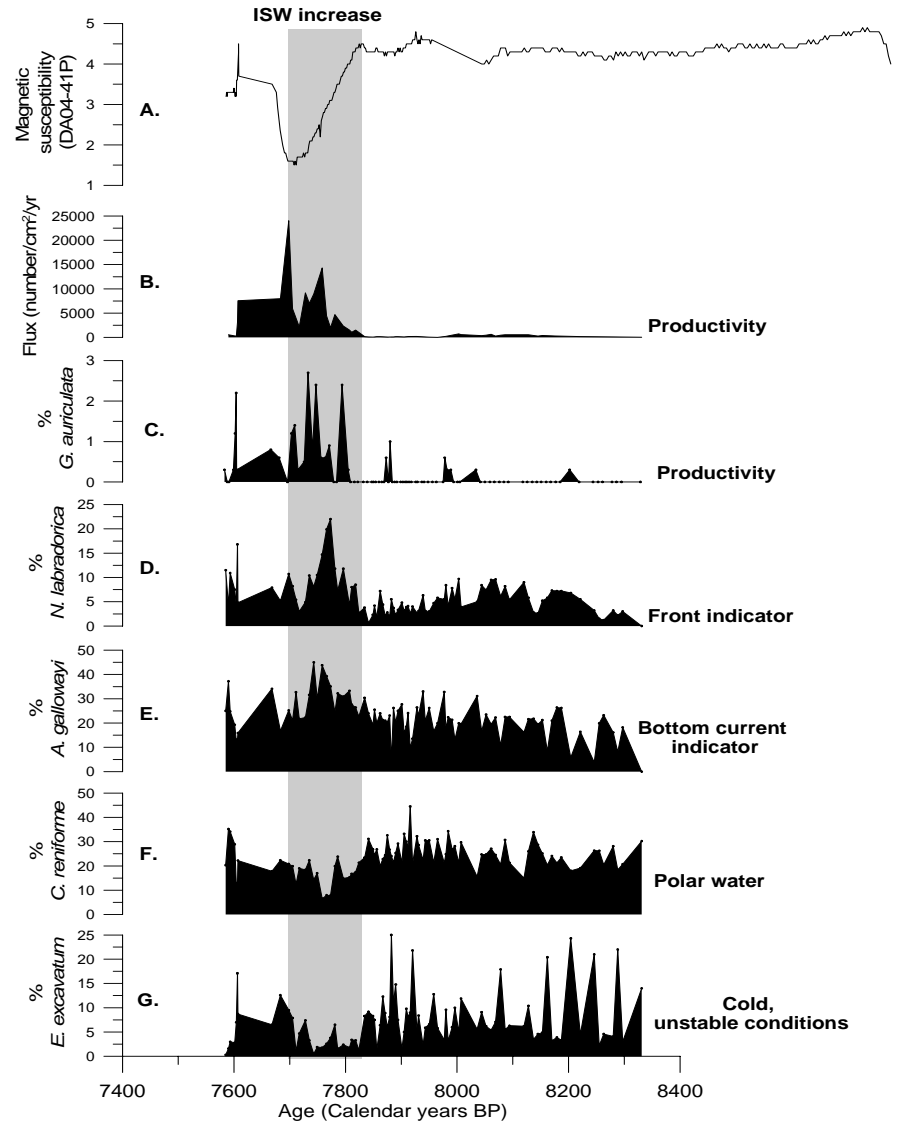

4, 1219-1235, 2008

$8.2 \mathrm{ka}$ event related to melting of the

Greenland Ice Sheet

H. Ebbesen et al.

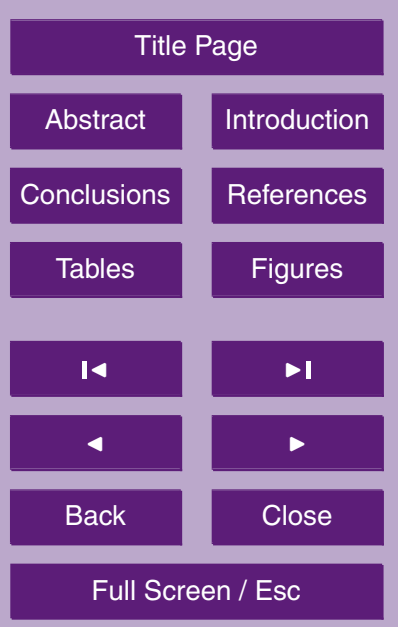

Printer-friendly Version

Interactive Discussion

Fig. 3. 


\section{2 ka event related to melting of the \\ Greenland Ice Sheet \\ H. Ebbesen et al.}

Fig. 3. A detailed study of the early Holocene of core DA04-41P. A-E: the frequencies of the most important benthic foraminiferal species $(100-1000 \mu \mathrm{m})$ in core DA04-41P. F shows the flux of benthic foraminifera. Due to extreme surface water characteristics associated with meltwater outflow, the planktic foraminiferal fauna in these cores is extremely poor or non-existent. To obtain a statistically qualified dataset we aimed at analyzing at least 300 benthic foraminifera in each sample, but a minimum of 60 specimens for one sample was accepted. The flux of benthic foraminifera was calculated assuming a mean sediment density of $1.8 \mathrm{~g} / \mathrm{cm}^{3}$. It has been possible to achieve an ultra-high resolution, $4-15$ years $/ \mathrm{cm}$ of the benthic foraminiferal analysis in core DA04-41P. G shows the MS during the same period. $\mathrm{H}$ : the land trace element of Fe (iron), and I: the Ti (titanium), both measured in cps (counts per second $\times 1000$ ). The X-ray fluorescence data provided us with the chemical composition of the sediment, among others the intensity of the elements iron and titanium, presented here. ISW = Irminger Sea Water.
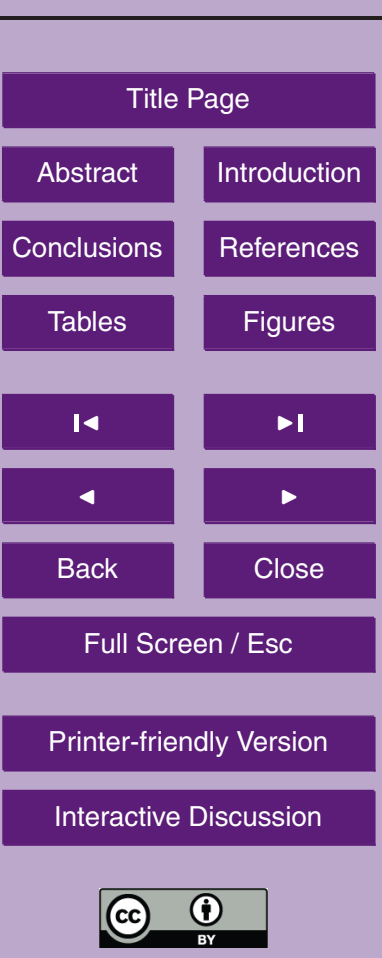


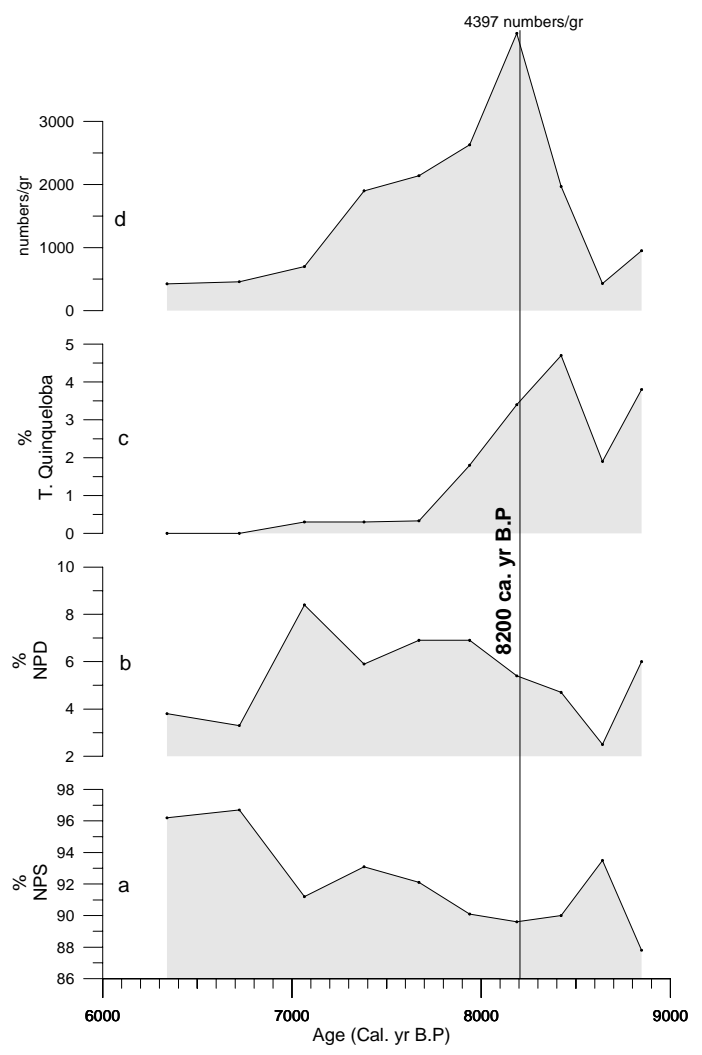

Fig. 4. A detailed study of the planktic foraminifera fauna in core DA04-31P, during the period from $9000-6000$ cal yr BP. (a) \% of Neogloboquadrina pachyderma sinistral (NPS); (b) \% of Neogloboquadrina pachyderma dextral (NPD); (c) \% of Turborotalita quinqueloba, and (d) the production of planktic foraminifera (numbers/gram sediment).
4, 1219-1235, 2008

8.2 ka event related to melting of the

Greenland Ice Sheet

H. Ebbesen et al.

\section{Title Page}

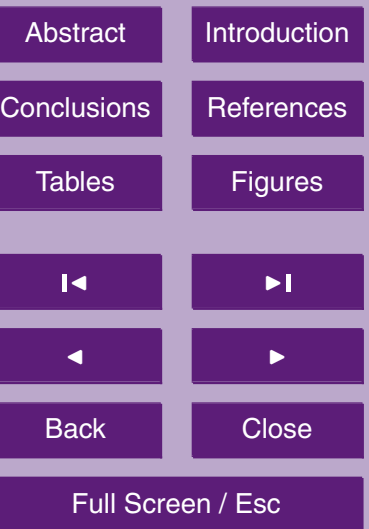

Printer-friendly Version

Interactive Discussion 